\title{
Taro [Colocasia esculenta (L.) Schott] production in Japan: Present state, problems and prospects
}

\author{
Tetsuo MIKAMI ${ }^{1,2}$, Sakio TSUTSUI ${ }^{1}$
}

Received September 27, 2019; accepted October 10, 2019. Delo je prispelo 27. septembra 2019, sprejeto 10. oktobra 2019.

Pridelovanje tara [Colocasia esculenta (L.) Schott] na Japonskem: trenutno stanje, problemi in perspektive

Izvleček: Taro [Colocasia esculenta (L.) Schott], predstavnik družine kačnikov (Araceae), je vegetativno razmnoževana poljščina z užitnimi čebulastimi gomolji (kormi, kormiči), listnimi peclji in listnimi ploskvami. Po razpoložljivih podatkih naj bi taro izviral iz južne centralne Azije, verjetno iz tropskih predelov med Indijo in Indonezijo. Poljščina naj bi dosegla Japonsko v $10^{\text {th }}$ stoletju pred Kristusom. Na nekaterih območjih Japonske je bil taro vsakodnevna hrana pred začetkom gojenja riža, danes se goji predvsem kot korenasta zelenjava. Čebulasti gomolji tara (kormi) so odličen vir ogljikovih hidratov in bogati na esencialnih mineralih, vitaminih in prehranskih vlakninah. Japonci so že od nekdaj stkali s poljščino socio-kulturne povezave, ko je bil taro postrežen na tradicionalnik praznikih in ob sezonskih dogodkih. Kljub tako veliki vrednosti, je gojenje tara $\mathrm{v}$ zadnjih desetletjih upadalo. Pripomniti je še potrebno, da je bilo genetskemu izbolšanju tara posvečeno premalo pozornosti. $\mathrm{V}$ tem pregledu je podan poskus zbiranja podatkov o komercialni pridelavi in uporabi tara na Japonskem kot tudi agronomske lastnosti vodilnih sort $\mathrm{v}$ pričakovanju, da bodo te informacije pomagale razumeti težave in prihodnost gojenja tara na Japonskem.

Ključne besede: agronomske lastnosti; žlahtnenje; korm; kormič́; sorta; zgodaj dozorevajoči genotip; taro; tradicionalan hrana 


\section{INTRODUCTION}

Taro [Colocasia esculenta (L.) Schott] is an ancient monocotyledonous crop belonging to the Araceae family. It is widely grown, with current worldwide production at nearly 10.2 million metric tonnes on nearly 1.7 million hectares (FAO, 2019). Nigeria produces the largest acreage (831,000 ha) of taro followed by Cameroon (227,000 ha), Ghana (184,000 ha), China (95,000 ha) and Côte d'Ivoire (67,000 ha) (FAO, 2019). According to Bown (2000), about 400 million people include taro in their diets, and in Japan it is primarily grown as a root vegetable. The plant consists of a central corm (mother tuber) from which cormels (side tubers), roots and shoots arise (Deo et al., 2009; Devi et al., 2016). While corms and cormels are economically the most important parts of the taro crop, petioles are also consumed by Japanese people (Matthews, 2004).

There is a variety of taro cultivars adapted to a range of microenvironments, from swidden fields and rainfed agriculture to paddy fields and swamps throughout the world (Chair et al., 2016). Among cultivated taros, two distinct botanical varieties are recognized, viz., var. antiquorum (Schott) Hubbard and Rehder (agronomically referred to as the "eddoe" type of taro) and var. esculenta (referred to as the "dasheen" type of taro) (Deo et al., 2009; Manner \& Taylor, 2011; Devi, 2012). The eddoe type has a small or medium-sized central corm (unsuitable for use as food) and a number of edible side cormels, whereas the dasheen type is distinguished by the possession of a large edible central corm and very few side cormels (Deo et al., 2009; Devi, 2012). Most of the taros grown in Japan are of eddoe type (Figure 1).

Japanese people have formed socio-cultural connections to taro since olden times (Nishimoto et al., 2009; Takeuchi \& Nagashima, 2012). For instance, taro has been the crop of choice for traditional feasting and seasonal events described later. It is well known that taro is an excellent source of carbohydrates (Deo et al., 2009). The crop is also emerging as a health food because of its richness in vitamins, potassium, phosphorus, calcium, magnesium, dietary fiber and so forth (Deo et al., 2009; Bhattacharjee et al., 2014). Despite having so much value, taro cultivation in Japan has shown declining trends in the past several decades (https://www.vegetable.alic.go.jp/yasaijoho/senmon/0510/ senmon.html). To make taro an attractive farm crop, there is a need to put more research and funds in the cultivar development and crop management practices for improving yield, enhancing the tolerance to biotic and abiotic stresses and expanding the cultivation area. This paper begins by providing an overview of the production and uses of taros in Japan. The paper describes the agronomic characteristics of representative taro cultivars and finally, focuses on the early maturing genotypes that are tolerant to cold northern climate and considered as useful genetic resources for commercial taro cultivation under normally unfavorable growth conditions.

\section{ORIGIN AND DISPERSAL INTO JAPAN}

Taro most likely originated in the tropics ranging from India to Indonesia, with subsequent eastwarddispersal to China, Japan and the Pacific Islands (Devi, 2012; Helmkampf et al., 2018). From Asia, the crop also spread westward to Arabia, the Mediterranean region and Africa (Devi, 2012; Chair et al., 2016; Ebert \& Waqainabete, 2018). It has been proposed that taro was introduced into Japan during the late Jomon period ( $10^{\text {th }}$ century B.C.), presumably earlier than the beginning of rice cultivation (Nakao, 1966; Sasaki, 1971; Hirai et al., 1989). Several lines of evidence suggest that there were at least two different dispersal routes of taro into Japan: one route from Taiwan via the Ryukyu Islands and the other route directly from China (Kumazawa et al., 1956; Matthews er al., 1992; Matsuda \& Nawata 1999). In the past, taro was one of the most important starchy crops in Japan, and at least 11 cultivars were

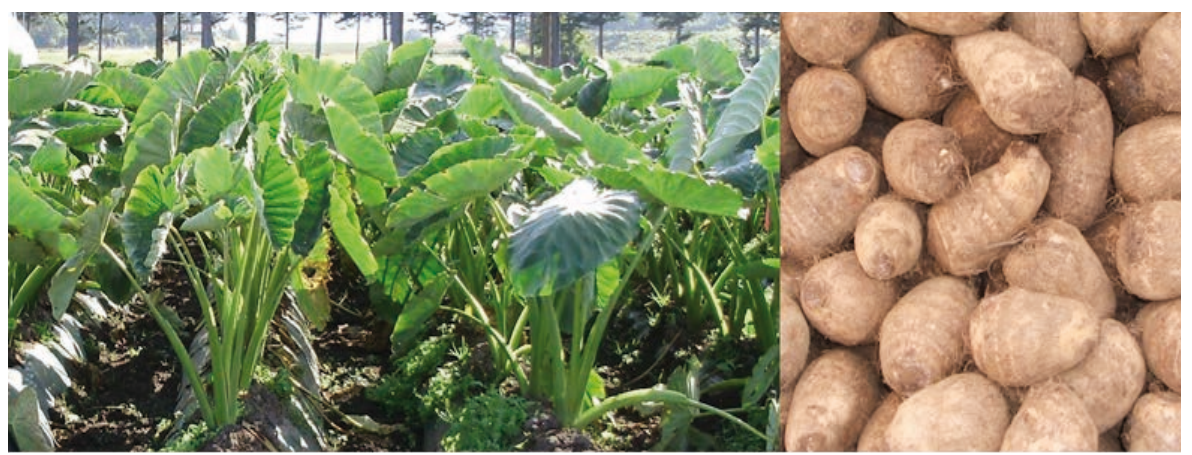

Figure 1: Taro plants (eddoe type) cultivated in the field (left panel) and cormels (right panel) (Photo: M. Kamei). 
already recognized by the early 1600's (Kumazawa et al., 1956).

\section{COMMERCIAL PRODUCTION}

The annual taro production in Japan has been as much as 148,600-172,500 tonnes which was harvested from approximately 12,700 ha during the recent six years (2012-2017) (Table 1). The current production is ca. $40 \%$ of what it was in the 1980's [for instance, taro was harvested from 29,000 ha with a total yield of 400,000 tonnes in 1982 (https://www.yasainavi.com/ graph/category/ca = 23)] (Table 1$)$. Taro farming has been on the decline throughout the country (https:// www.vegetable.alic.go.jp/yasaijoho/senmon/0510/senmon.html), though the total yield of taro has remained fairly steady in the recent past (see Table 1).

One of the reasons that have direct implication in the decline is undoubtedly the demographic change taking place in the major taro growing villages. Younger populations are leaving the villages to urban areas for education, job and business opportunities. The leftover rural workforce is aging, thus there are not sufficient hands to work on the farm. Many farmers have reduced taro planting to divert more land under cash crops which give them better returns. Another reason is, as far as we can see, the change in dietary habits (Ashkenazi \& Jacob, 2003; Kusaka et al., 2016). Rice, tubers (including taro) and starchy roots, vegetables, minor cereals and fish were the mainstays of the Japanese diet for some time after the World War II. The period from 1955 to 1970 was a time of diversification and westernization of eating habits. Household incomes rose during the postwar economic growth, urban areas expanded, and the consumption of milk, butter, meat, and eggs grew rapidly. On the contrary, the consumption of traditional Japanese foodstuffs such as rice, tubers and root crops decreased. In fact, taro consumption per capita per year has reduced from over $1,370 \mathrm{~g}$ in the late 1960 's to $623 \mathrm{~g}$ in 2014 (https://www.vegetan.alic.go.jp/toukeiyouran. html). It is also worth mentioning that the household food budget allocated to fresh products (including fresh vegetables) has declined since 1970's because Japanese people have increased consumption of foods with greater convenience of preparation (Campo \& Beghin, 2005).

\section{USES}

As pointed out by Matthews (2010), the continuing popularity of taro in Japan is conceivably attributed to a generally high regard for traditional foods and the continuous dissemination of cooking methods via the mass-media. Taro has been actually an important food to share with family and/or community people in gathering on special occasions. This is well illustrated by a popular dish called 'Chikuzen-ni' which is made of simmered chickin, taro cormels, lotus roots and some vegetables (http://www.japanfoodaddict.com/osechi/ chikuzen-ni). The dish is often eaten when celebrating the arrival of a new year throughout the country.

Another example is a traditional soup called 'Imoni'; in the northeast region of Japan, groups of people prepare this soup around a fire near a river in celebration of the crop harvest during the late summer and early autumn. The soup contains taro, vegetables, mushrooms and thinly sliced meet (beef or pork). Either soy sauce or miso paste (fermented soybean paste) is included to flavor the soup (http://www.ajfarm.com/ yamagata/12791).

Small taro cormels are steamed with their skins on and eaten after pealing their skins and slightly salting (http://www.japan-word.com/kinukatsugi). This simple dish (known as 'Kinukatsugi') is usually served for the moon viewing festival in mid-autumn. It should also be added that taro corms and cormels are frequently prepared through simmering in traditional broth and soy sauce in home-cooked dishes (Matthews, 2004; Nishimoto et al., 2009). A few cultivars bear edible petioles; petioles are commonly either peeled and cooked in soups or served after pickling in vinegar (Matthews, 2004). In addition, taro is processed to make value-added products such as chips, cakes, taro flour and local alcoholic beverages (Takeuchi \& Nagashima, 2012).

\section{MAJOR CULTIVARS}

The Japanese archipelago spans a wide range of latitudes and offers very diverse physical environments for agriculture (Matthews, 2010). Apparently, tropical forms of taro reach their northern limit in Kyushu island at about $33^{\circ} \mathrm{N}$, whereas temperate forms extend

Table 1: Production and cultivation area of taro in Japan. Source: MAFF. (2019)

\begin{tabular}{lrrrrrr}
\hline & \multicolumn{1}{c}{2012} & \multicolumn{1}{c}{2013} & 2014 & \multicolumn{1}{c}{2015} & \multicolumn{1}{c}{2016} & \multicolumn{1}{c}{2017} \\
\hline Cropping acreage (ha) & 13,400 & 13,000 & 12,900 & 12,500 & 12,200 & 12,000 \\
Total yield (t) & 172,500 & 162,100 & 165,700 & 153,300 & 154,600 & 148,600 \\
\hline
\end{tabular}


Table 2: List of representative taro cultivars grown in Japan

\begin{tabular}{ll}
\hline $\begin{array}{l}\text { Cultivar } \\
\text { (Ploidy) }\end{array}$ & Agronomic characteristics \\
\hline $\begin{array}{l}\text { Ishikawa-wase } \\
\text { (Triploid) }\end{array}$ & $\begin{array}{l}\text { An early-maturing cultivar that produces many, rather small globoid cormels and is mostly cultivated in } \\
\text { the western area of Japan. The cormels are smooth in texture when cooked. As in 'Dotare' and 'Hasuba-imo' } \\
\text { only cormels are edible. This cultivar most likely arose from an ancient landrace 'Kurojiku' by bud mutation } \\
\text { (Hirai et al., 1989). }\end{array}$ \\
$\begin{array}{l}\text { Dotare } \\
\text { (Triploid) }\end{array}$ & $\begin{array}{l}\text { A popular cultivar that forms many oval cormels with soft and sticky flesh, and exhibits moderate tolerance } \\
\text { to cold climate. Mainly cultivated in eastern Japan. }\end{array}$ \\
$\begin{array}{l}\text { Hasuba-imo } \\
\text { (Triploid) }\end{array}$ & $\begin{array}{l}\text { Characterized by horizontally lifted leaf laminae. The cormels are globular in shape, and have somewhat } \\
\text { sticky texture with a sweet taste upon cooking. }\end{array}$ \\
$\begin{array}{l}\text { Akame } \\
\text { (Triploid) }\end{array}$ & $\begin{array}{l}\text { A late-maturing cultivar characterized by reddish petioles and buds. Elliptical corms and cormels have } \\
\text { mealy texture with a sweet taste when cooked. Both central corm and cormels are used as food. }\end{array}$ \\
$\begin{array}{l}\text { Yatsugashira } \\
\text { (Diploid) }\end{array}$ & $\begin{array}{l}\text { A number of buds sprout from a single corm. The flesh of corm and cormels has bright creaming color and } \\
\text { is flaky in texture with a slightly sweet flavor. The corm, cormels and petioles together constitute the edible }\end{array}$ \\
& harvest.
\end{tabular}

to about $41^{\circ} \mathrm{N}$, in northern Honshu (the main island of Japan).

More than one hundred taro cultivars (mostly local landraces) have been cultivated in the country (Hirai et al., 1989). As regards cultivar identification, however, complications arise from the fact that different genotypes can be given identical or similar names and different names can be applied to the same genotypes. With this in mind, Kumazawa et al. (1956) classified the Japanese cultivars into 14 groups primarily based on the morphology of floral and vegetative organs. The classification was basically confirmed by the analyses using isozymes, tuber proteins, and ribosomal and mitochondrial DNAs (Hirai et al., 1989; Matthews et al., 1992; Isshiki et al., 1998).

Table 2 shows the agronomic characteristics of representative taro cultivars currently grown in Japan. These cultivars have been vegetatively propagated, and hence there is almost no genetic variation within the cultivars (Hirai et al., 1989; Matthews et al., 1992; Isshiki et al., 1998). Moreover, it seems likely that much of the phenotypic variations among the cultivars is ascribed to somatic mutations, selection or introduction of new genotypes from the outside of Japan (Hirai et al., 1989; Isshiki et al., 1998). Diploids $(2 \mathrm{n}=2 \mathrm{x}=28$ chromosomes) and triploids $(2 \mathrm{n}=3 \mathrm{x}=42$ chromosomes) occur in Japanese taros (Kumazawa et al., 1956). Triploids are believed to arise when unreduced gametes $(1 \mathrm{n}=2 \mathrm{x}=28)$ from one parent flower meet normal gametes from another parent flower (Isshiki et al., 1999). Most of the Japanese cultivars are triploids, thus leaving one with the inference that triploids may be endowed with better adaptability and enhanced hardiness to unfavorable climates in the higher latitudes (Tahara et al., 1999; Ochiai et al., 2001; Ebert \& Waqainabete, 2018).

\section{A HYBRID CULTIVAR 'HIMEKAGUYA'}

In Japan, little attention has been devoted to the genetic improvement of taro. The primary reason for this is the difficulty of hybrid breeding due to the inherent infertility of triploid taros predominantly grown in the country (Matthews et al., 1992). Additionally, diploid taros hardly ever flower under natural conditions in Japan, and most plants complete their field life without flowering at all (Matthews et al., 1992). The improvement programmes have been exclusively dependent upon the exploitation of the existing genetic variability among the cultivars (Banjaw, 2017). However, changes in the environment (e.g., new pests and diseases, and climatic changes), crop production technology, processing and marketing continuously require new cultivars (Ivančič \& Lebot, 2000).

The discovery of gibberellic acid as an aid in promoting flowering in taro has prompted a fraction of plant breeders to look at the possibility of producing taro hybrids (Wilson \& Cable, 1984). The breeding programme at the Ehime Research Institute of Agriculture, Forestry and Fisheries, released its first diploid hybrid cultivar 'Himekaguya' in 2007 (Nakagawa et al., 2016). This cultivar apparently yields more than its parents (diploid local landraces 'Takenoko-imo' and 'Touno-imo') and has good market acceptability due to its favorable eating quality (e.g., slightly mealy in texture and sweet taste) (Nakagawa et al., 2016).

\section{CONCLUSIONS}

Over the last few decades, insufficient quantities of taro have been grown domestically; in 2014, about 34,000 tonnes of pre-cooked frozen taro were imported 
Table 3: Mean values of four characters of two early-maturing taro cultivars 'Dotare' and 'Yamato-wase'. Source: Shiga et al. (2011)

\begin{tabular}{llllll}
\hline & $\begin{array}{l}\text { Plant height } \\
\text { Cultivar }\end{array}$ & $\begin{array}{l}\text { Foliage mass } \\
(\mathrm{cm})\end{array}$ & $\begin{array}{l}\text { Number of cormels } \\
\text { per plant }\end{array}$ & \multicolumn{2}{l}{ Cormel yield $\left.(\mathrm{kg} \mathrm{a})^{-1}\right)^{*}$} \\
\cline { 5 - 6 } Dotare & 106 & 1,677 & 13.2 & Marketable & Unmarketable \\
Yamato-wase & 95 & 1,325 & 11.7 & 138 & 121 \\
\hline
\end{tabular}

Seed corms were planted in rows $100 \mathrm{~cm}$ apart and $40 \mathrm{~cm}$ distant within row on May 19, 2010. The ridges were covered with polyethylene film mulch. All plots received 0.8-1.6-2.0 (N- $\left.\mathrm{P}_{2} \mathrm{O}_{5}-\mathrm{K}_{2} \mathrm{O}\right) \mathrm{kg} \mathrm{a}^{-1}$ fertilizer. The four characters were recorded at harvest (October 15).

* Only cormels are edible in the two cultivars examined.

to supplement domestic production (https://www.vegetable.alic.go.jp/yasaijoho/senmon/0510/senmon.html). Nevertheless, domestically grown produce is generally preferred to imported, not only in terms of quality and taste, but also safety. Taro requires an average daily temperature above $21{ }^{\circ} \mathrm{C}$ for normal growth and does not tolerate frost (Onwneme, 1999), which restricts the increased production of the crop in Japan. Commercial taro production in the country is indeed confined to the temperate eastern, central and southwestern areas. Taro cultivation in the northernmost island, Hokkaido (latitude: $41^{\circ} \mathrm{N}-46^{\circ} \mathrm{N}$ ) has been considered to be impracticable due to the climate condition, especially short summer; in this prefecture, the daily average temperature generally rises above $21^{\circ} \mathrm{C}$ only in July and August (http://www.data.jma.go.jp). However, it should be emphasized that Hokkaido accounts for $25 \%$ of Japan's total cultivated acreage (http://www.pref.hokkaido.lg.jp/ns/nsi/genjyou_english_3101.pdf) and is frequently called as 'food storage' in Japan. Moreover, farm sizes (the cultivated area per farm household) in Hokkaido are on average 13 times greater than those of any other prefectures. Farmers mostly run their business on a large scale and full-time basis; in Hokkaido, business farm households, whose principal income is farming and which have at least one family member engaged in self-employed farm work for more than 60 days per year, account for $73 \%$ in the total prefectural farm households, compared with $20 \%$ in the other prefectures (OECD, 2009; http://www.pref.hokkaido.lg.jp/ ns/nsi/genjyou_english_3101.pdf). Taro genotypes with tolerant ability to low temperature would enable this crop species to be cultivated under normally unfavorable culture conditions.

Interestingly, two early maturing genotypes have recently proven tolerant to a cooler climate (Shiga et al., 2011). The field trial for growth and yield performance of two cultivars ('Dotare' and 'Yamato-wase') was carried out during May to October of 2010 at the experimental farm $\left(43^{\circ} 3^{\prime} \mathrm{N}\right.$ latitude and $141^{\circ} 5 \mathrm{E}$ longitude, ca. $100 \mathrm{~m}$ a.s.l) situated in Hokkaido. As shown in Table
3 , the two genotypes produced yields comparable to or exceeding the average national yields of $1,290 \mathrm{~kg}$ $10 \mathrm{a}^{-1}$ (MAFF, 2019). Similar results were found in a separately performed evaluation of yield parameters (M. Kamei, personal communication, May 28, 2019), implying that some early maturing cultivars would be useful genotypes for commercial taro cultivation under unfavorable growth conditions.

Nowadays, crop genomics provides plant breeders with a new set of tools and resources that allow the study of the genotype and its relationship with the phenotype (Pérez-de-Castro et al., 2012; Silva Dias, 2015). Genomic approaches are particularly useful when dealing with complex traits such as tolerance to cold climate and yield, since these traits usually have a multi-genic nature and are greatly influenced by the environment (Ivančič \& Lebot, 2000). The molecular genetic researches and genetic basic data in taro are unfortunately limited in comparison with major crops (Liu et al., 2015). Nevertheless, the first taro linkage maps were generated with mainly amplified fragment length polymorphism (AFLP) and some simple sequence repeat (SSR) markers (Quero-García et al., 2006). Most recently, Soulard et al. (2017) identified a great number of single nucleotide polymorphism (SNP) loci to construct high-density genetic maps. Further efforts need to be directed towards identification and validation of a greater number of molecular markers and generating linkage maps with deeper coverage that can assist breeders in quantitative trait loci (QTL) dissection and marker assisted breeding.

\section{ACKNOWLEDGEMENTS}

The authors gratefully thank Mr. Makoto Nakamura (Managing Director, Hokkaido Agricultural Laboratory for Business Development) for support throughout this work and Mr. Masaru Kamei for valuable comments. 


\section{REFERENCES}

Ashkenazi, M., Jacob, J. (2003). Food culture in Japan. Westport, Connecticut: Greenwood Press.

Banjaw, D. T. (2017). Review of taro (Colocasia esculenta) genetics and breeding. Journal of Horticulture, 4, 196. https:// doi.org/10.4172/2376-0354.1000196

Bhattacharjee, M., Tarafdar, J., Sadhukhan, R. (2014). Assessment of genetic diversity of some indigenous collections of upland taro [Colocasia esculenta var. antiquorium (L.) Schott] for selection of genotypes aiming at improvement in breeding programme. IOSR Journal of Agriculture and Veterinary Science, 7(7), 31-43. https://doi. org/10.9790/2380-07713143

Bown, D. (2000). Aroids. Plants of the arum family. Portland: Timber Press.

Campo, I. S., Beghin, J. C. (2005). Dairy food consumption, production, and policy in Japan. CARD Working Papers. 418. https://lib.dr.iastate.edu/card_workingpapers/418

Chaïr, H., Traore, R. E., Duval, M. F., Rivallan, R., Mukherjee, A., Aboagye, L. M., ...Lebot, V. (2016). Genetic diversification and dispersal of taro (Colocasia esculenta (L.) Schott). PLoS ONE, 11(6), e0157712. https://doi.org/10.1371/journal.pone. 0157712

Deo, P. C., Tyagi, A. P., Taylor, M., Becker, D. K., Harding, R. M. (2009). Improving taro (Colocasia esculenta var. esculenta) production using biotechnological approaches. South Pacific Journal of Natural Science, 27, 6-13. https:// doi.org/10.1071/SP09002

Devi, A. A. (2012). Genetic diversity analysis in taro using molecular markers - An overview. Journal of Root Crops, 38(1), 15-25.

Devi, K. S., Singh, K. J., Devi, A. K. B., Mandal, J., Singh, H. B. (2016). Morphological evaluation of taro (Colocasia esculenta Linn.) genotypes collected from Manipur State of India and their yield performance. Journal of Root Crops, 42(2), 18-23.

Ebert, A. W., Waqainabete, L. M. (2018). Conserving and sharing taro genetic resources for the benefit of global taro cultivation: A core contribution of the Centre for Pacific Crops and Trees. Biopreservation and Biobanking, 16(5), 361-367. https://doi.org/10.1089/bio.2018.0017

FAO. (2019). FAOSTAT database. Retrieved from https:// www.fao.org/faostat/en/\#home

Helmkampf, M., Wolfgruber, T. K., Bellinger, M. R., Paudel, R., Kantar, M. B., Miyasaka, S. C., Shintaku, M. (2018). Phylogenetic relationships, breeding implications, and cultivation history of Hawaiian taro (Colocasia esculenta) through genome-wide SNP genotyping. Journal of Heredity, 109(3), 272-282. https://doi.org/10.1093/jhered/esx070

Hirai, M., Sato, T., Takayanagi, K. (1989). Classification of Japanese cultivars of taro (Colocasia esculenta (L.) Schott) based on electrophoretic pattern of the tuber proteins and morphological characters. Japanese Journal of Breeding, 39, 307-317. https://doi.org/10.1270/jsbbs1951.39.307

Isshiki, S., Nakamura, N., Tashiro, Y., Miyazaki, S. (1998). Classification of the cultivars of Japanese taro [Colocasia esculenta (L.) Schott] by isozyme analyses. Journal of the
Japanese Society for Horticultural Science, 67(4), 521-525. https://doi.org/10.2503/jjshs.67.521

Isshiki, S., Otsuka, K., Tashiro, Y., Miyazaki, S. (1999). A probable origin of triploids in taro [Colocasia esculenta (L.) Schott]. Journal of the Japanese Society for Horticultural Science, 68(4), 774-779. https://doi.org/10.2503/jjshs.68.774

Ivančič, A., Lebot, V. (2000). The genetics and breeding of taro. Séries Repères, Montpellier: CIRAD

Kumazawa, S., Niuchi, K., Honda, F. (1956). Classification of the taro varieties in Japan. Journal of the Japanese Society for Horticultural Science, 25(1), 1-10. https://doi. org/10.2503/jjshs.25.1 (in Japanese)

Kusaka, S., Ishimaru, E., Hyodo, F., Gakuhari, T., Yoneda, M., Yumoto, T., Tayasu, I. (2016). Homogeneous diet of contemporary Japanese inferred from stable isotope ratios of hair. Scientific Reports, 6, 33122. https://doi.org/10.1038/ srep.33122

Liu, H., You, Y., Zheng, X., Diao, Y., Huang, X., Hu, Z. (2015). Deep sequencing of the Colocasia esculenta transcriptome revealed candidate genes for major metabolic pathways of starch synthesis. South African Journal of Botany, 97, 101106. https://dx.doi.org/10.1016/j.sajb.2014.11.008

MAFF (Ministry of Agriculture, Forestry and Fisheries, Japan). (2019). Statistics of taro production. Retrieved from http://www.maff.go.jp/j/tokei/kouhyou/sakumotu/index. html (in Japanese)

Manner, H. I., Taylor, M. (2011). Farm and forestry production and marketing profile for taro (Colocasia esculenta). In C. R. Elevitch (Ed.), Specialty crops for Pacific Island agroforestry. (pp. 1-34). Holualoa, Hawaii: Permanent Agriculture Resources (PAR). http://agroforestry.net/scps

Matsuda, M., Nawata, E. (1999). Isozyme variation in taro, Colocasia esculenta (L.) Schott, from China, Taiwan, the Ryukyu Islands, and Japan: Its dispersal into Japan. Tropics, 8(4), 397-407. https://doi.org/10.3759/tropics.8.397

Matthews, P. J. (2004). Genetic diversity in taro, and the preservation of culinary knowledge. Ethnobotany Research and Applications, 2, 55-71. https://doi.org/10.17348/ era.2.0.55-71

Matthews, P. J. (2010). An introduction to the history of taro as a food. In R. V. Ramanatha, P. J. Matthews, P. B. Eyzaguirre, D. Hunter (Eds.), The global diversity of taro: Ethnobotany and conservation (pp. 6-29). Rome: Bioversity International.

Matthews, P. J., Matsushita, Y., Hirai, M. (1992). Ribosomal and mitochondrial DNA variation in Japanese taro, Colocasia esculenta (L.) Schott. Japanese Journal of Breeding, 42, 825833. https://doi.org/10.1270/jsbbs1951.42.825

Nakagawa, T., Asaumi, H., Tamaki, M., Morikawa, T. (2016). 'Himekaguya', a new taro cultivar in Ehime prefecture. Bulletin of the Ehime Research Institute of Agriculture, Forestry and Fisheries, 8, 19-23. (in Japanese)

Nakao, S. (1966). The origin of cultivated plants and agriculture. Tokyo: Iwanami-shoten. (in Japanese)

Nishimoto, T., Maegawa, H., Yamaguchi, T., Takamura, H., Matoba, T. (2009). Varietal differences in the cookability of taro corms. Journal of Cookery Science of Japan, 42(2), 129-134. https://doi.org/10.11402/cookeryscience.42.129 (in Japanese) 
Ochiai, T., Nguyen, V. X., Tahara, M., Yoshino, H. (2001). Geographical differentiation of Asian taro, Colocasia esculenta (L.) Schott, detected by RAPD and isozyme analyses. Euphytica, 122, 219-234. https://doi. org/10.1023/A:1012967922502

OECD. (2009). Evaluation of agricultural policy reforms in Japan. Paris: OECD Publishing. https://doi. org/10.1787/9789264061545-en

Onwueme, I. (1999). Taro cultivation in Asia and the Pacific. Bangkok: RAP Publication.

Pérez-de-Castro, A. M., Vilanova, S., Cañizares, J., Pascual, L., Blanca, J. M., Diez, M. J., Picó, B. (2012). Application of genomic tools in plant breeding. Current Genomics, 13(3), 179-195. https://doi.org/10.2174/138920212800543084

Quero-García, J., Courtois, B., Ivančič, A., Letourmy, P., Risterucci, A. M., Noyer, J. L., Lebot, V. (2006). First genetic maps and QTL studies of yield traits of taro (Colocasia esculenta (L.) Schott). Euphytica, 151, 187-199. https://doi. org/10.1007/s10681-006-9139-y

Sasaki, K. (1971). The agriculture before rice cultivation. Tokyo: Nippon Hoso Shuppan Kyokai. (in Japanese)

Shiga, Y., Nakayasu, K., Fujiwara, K., Tsutsui, S. (2011). Growth and yield of early-maturing taro cultivars grown in mulched ridges. Proceedings of the Hokkaido Society for Horticultural Research, 44, 40-41. (in Japanese)
Silva Dias, J. C. (2015). Plant breeding for harmony between modern agriculture production and the environment. Agricultural Science, 6, 87-116. http://doi.org/10.4236/ as.2015.61008

Soulard, L., Mournet, P., Guitton, B., Chaïr, H. (2017). Construction of two genetic linkage maps of taro using single nucleotide polymorphism and microsatellite markers. Molecular Breeding, 37, 37. https://doi.org/10.1007/ s11032-017-0646-4

Tahara, M., Suefuji, S., Ochiai, T., Yoshino, H. (1999). Phylogenetic relationships of taro, Colocasia esculenta (L.) Schott and related taxa by non-coding chloroplast DNA sequence analysis. Aroideana, 22, 79-89.

Takeuchi, J., Nagashima, T. (2012). Low-malt beer brewing using of taro (Colocasia esculenta (L.) Schott) as a secondary material. Nippon Shokuhin Kagaku Kogaku Kaishi, 59(3), 146-152. https://doi.org/10.3136/nskkk.59.146 (in Japanese)

Wilson, J. E., Cable, W. J. (1984). Promotion of flowering, seed production and seedling screening in minor edible aroids. In Proceedings of the 6th Symposium of the International Society for Tropical Root Crops (pp. 151-156). Lima: International Potato Center. 